\title{
Histopathological study of endometrium in dysfunctional uterine bleeding
}

\author{
Malarvizhi Loganathan*, Meera Krishnakumar
}

Department of Obstetrics and Gynecology, Government Dharmapuri Medical College, Dharmapuri, Tamil Nadu, India

Received: 25 June 2018

Revised: 26 July 2018

Accepted: 28 July 2018

\section{*Correspondence:}

Dr. Malarvizhi Loganathan,

E-mail: elamalar.me@gmail.com

Copyright: () the author(s), publisher and licensee Medip Academy. This is an open-access article distributed under the terms of the Creative Commons Attribution Non-Commercial License, which permits unrestricted non-commercial use, distribution, and reproduction in any medium, provided the original work is properly cited.

\begin{abstract}
Background: This study was undertaken to study the endometrial histology in patients presenting with abnormal uterine bleeding in the absence of palpable pelvic pathology, which helps in choosing the right modality of treatment in a particular age group with a specific histological change. The study of endometrium in dysfunctional uterine bleeding was undertaken to correlate clinical presentations with histopathological studies and to correlate the distribution of histopathological findings in various age groups.

Methods: The present study was conducted in the Department of Obstetrics and Gynaecology at Govt. Dharmapuri Medical College and Hospital during the period 01.07.2017 to 31.05.2018. Patients presenting to Govt. Dharmapuri Medical College and Hospital with abnormal uterine bleeding form the material of this study. Cases have been selected by using purposive sampling technique.

Results: An ovulatory cycles were more common than ovulatory cycles in all age group. However, in patients with menorrhagia and polymenorrhagia majority had secretory endometrium (ovulatory cycles).

Conclusions: Majority of the patients were found in the reproduction age group with the maximum percentage in multiparous women. Menorrhagia was the commonest mode of presentation in all age group. Most of the patients with proliferative and secretory endometrium had normal sized uterus and normal looking endometrium.
\end{abstract}

Keywords: Endometrium, Hyperplasia, Metrorrhagia, Nulliparous, Ovulatory cycles, Perimenopausal

\section{INTRODUCTION}

Abnormal uterine bleeding is one of the commonest conditions for which patients seek advice in the gynaecological out patient department. On account of its doubtful aetiology and varied interpretation, it is designated by several names i. e., functional uterine haemorrhage, dysfunctional uterine bleeding, abnormal uterine haemorrhage, etc by different workers.

It indicates a group of disorders associated with endometrial bleeding not related to neoplasms, pregnancy, infections or trauma. The bleeding thus is the result of endocrine dysfunction, rather loosely attributed to some derangement of the hypothalamic-pituitaryovarian-endometrial axis.

Novak E pointed out that What we do know concerning the causation of functional bleeding pertain almost entirely to endocrine factors, but there are other cogs in the complicated machinery of menstrual function which may conceivably undergo aberrations of one sort or another-the musculature of the uterus, the vascular mechanism of the endometrium and the vasomotor apparatus. $^{1}$ 
Prostaglandin imbalance at the endometrial level i. e., the alterations in the ratio of vasoconstrictive prostaglandins (PG F2and and TXA2) and vasodilator prostaglandins (PGE2 and PGI2) has also been implicated in the causation of dysfunctional uterine bleeding (Paige Hertweck S).

Sutherland records his opinion in unmistakable language that, it is absolutely necessary to carry out dilatation and curettage in well established uterine bleeding irrespective of age and endometrium is to be studied histologically. ${ }^{2}$

The corroborative study with clinical date and study of endometrial histology would throw more light towards the concept of normal endometrium in cases of menorrhagia with no clinical evidence of any recognizable pathology in the pelvic organs (Joshi SK et al). ${ }^{3}$

The microscopical examination of endometrium bears the pivotal role in diagnosing the various etiopathological factors in cases of abnormal uterine bleeding. ${ }^{2,3}$ When no systemic or local pelvic cause is evident, histopathlolgical examination of the endometrium remains the only alternative to reach the diagnosis (Maheshwari V). ${ }^{4}$

So, this study was undertaken to study the endometrial histology in patients presenting with abnormal uterine bleeding in the absence of palpable pelvic pathology, which helps in choosing the right modality of treatment in a particular age group with a specific histological change.

The study of endometrium in dysfunctional uterine bleeding was undertaken to correlate clinical presentations with histopathological studies and to correlate the distribution of histopathological findings in various age groups.

\section{METHODS}

The present study was conducted in the Department of Obstetrics and Gynaecology at Government Dharmapuri Medical College and Hospital during the period 01.07.2016 to 30.06 .2017 .

Patients presenting to Government Dharmapuri Medical College and Hospital with abnormal uterine bleeding form the material of this study. Cases have been selected by using purposive sampling technique. Inclusion and exclusion criteria's followed in the study are:

\section{Inclusion criteria}

- Abnormal uterine bleeding of any type

- Patients belonging to any age group.

\section{Exclusion criteria}

- Pregnancy
- $\quad$ Tumors of the uterus (benign and malignant)

- Infection (endometritis)

- Intrauterine foreign bodies ex. IUCD.

- Coagulopathies (platelet disorder; clotting factor abnormalities)

- Exogenous hormones and Iatrogenic medications

- Endocrine disorder (disorder of thyroid, adrenal and diabetes mellitus).

In all the cases detailed history was obtained which included:

- Age, parity and fertility

- Amount, duration and pattern of uterine bleeding and its relation to puberty; recent delivery or abortion; and last menstrual period. ${ }^{4}$

- History to rule out secondary causes of dysfunctional uterine bleeding.

General, physical and systemic examination was done in an effort to find out the cause or effect of abnormal uterine bleeding.

Detailed pelvic examination was done to rule out organic palpable pelvic pathology.

Per speculum examination was done to know whether the vagina and the cervix are healthy; any discharge and its characters like- colour, odor and nature of the discharge; direction of the cervix and any lesion on the cervix.

Bimanual examination was done to know the:

- Direction, size, consistency and mobility of the uterus

- Tenderness or any mass in the fornices.

Per rectal examination was done in unmarried girls to exclude pelvic pathology.

Routine and specific investigations were done to rule out other factors responsible for abnormal bleeding which included:

- Hemoglobin percentage

- Peripheral blood smear study

- Ultrasound

- Coagulation profile

- Glucose intolerance assessment

- Thyroid and renal function tests

- Liver function tests

- viii Hormonal assay

Dilatation and curettage was done in adolescent girls to rule out tuberculosis in refractory patients when there is no response for hormonal therapy for 6 months. It was the initial investigation in reproductive and perimenopausal age group. 
In perimenopausal and postmenopausal women, the procedure of $\mathrm{D}$ and $\mathrm{C}$ was modified and fractional curettage was done.

Premenstrual D and C (5-6 days prior to menstruation) was done if the patient has got regular cycles and on the first day of the menstruation when cycles are irregular and during the bleeding phase when the patient was presented with continuous profuse bleeding. D and $\mathrm{C}$ was done in all patients either under IV sedation and paracervical block. While doing $\mathrm{D}$ and $\mathrm{C}$, following points were observed:

- Uterocervical length

- Regularity of the uterine cavity

- Amount and nature of the endometrium obtained

The curettings obtained were fixed in $10 \%$ formaldehyde solution, labelled and subjected for histopathological examination.

The Haematoxylin and Eosin staining was done in all the endometrial tissues obtained. The type of endometrium was noted and was correlated with clinical findings and age of the patient.

\section{RESULTS}

In the present study, maximum number of cases with dysfunctional uterine bleeding were found in reproductive age group 20 to 40 years $(60.40 \%)$ and minimum number occurred in the age group $<20$ years $(1.02 \%)$.

Table 1: Distribution of cases according to age group.

\begin{tabular}{|lll|}
\hline Age in years & Numbers & Percentage \\
\hline$<20$ & 2 & 1.02 \\
\hline $20-40$ & 119 & 60.40 \\
\hline$>40$ & 76 & 38.58 \\
\hline Total & 197 & 100.00 \\
\hline
\end{tabular}

The minimum age of the patient in the present study was 18 years and maximum age was 63 years. The range being 45 years.

Table 2: Distribution of cases according to parity.

\begin{tabular}{|lll|}
\hline Parity & Numbers & Percentage \\
\hline Nulliparous & 7 & 3.56 \\
\hline Uniparous & 5 & 2.53 \\
\hline $2-5$ & 178 & 90.35 \\
\hline 5 & 7 & 3.56 \\
\hline Total & 197 & 100.00 \\
\hline
\end{tabular}

The mean age in the present study was 39.3 years with a standard deviation of 8.2 years.
The maximum number of cases were found in multiparous women with parity 2-5 (90.35\%). The percentage was 3.56 both for nulliparous and the women with parity $>5$. The minimum number of cases were found in uniparous women, the percentage being 2.53 .

Table 3: Types of menstrual bleeding.

\begin{tabular}{|lll|}
\hline $\begin{array}{l}\text { Types of menstrual } \\
\text { bleeding }\end{array}$ & Numbers & Percentage \\
\hline Menorrhagia & 70 & 35.54 \\
\hline Metrorrhagia & 41 & 20.81 \\
\hline $\begin{array}{l}\text { Metropathia } \\
\text { haemorrhagica }\end{array}$ & 39 & 19.80 \\
\hline Polymenorrhagia & 19 & 9.64 \\
\hline Continuous bleeding & 19 & 9.64 \\
\hline Postmenopausal bleeding & 9 & 4.57 \\
\hline Total & 197 & 100.00 \\
\hline
\end{tabular}

Menorrhagia was the main symptom in 70 cases constituting $35.54 \%$ of all the cases.

Metrorrhagia and metropathia haemorrhagica formed the second and third common menstrual disorders with the percentage of 20.81 and 19.80 respectively. $4.57 \%$ of the patients presented with postmenopausal bleeding.

Table 4: Histologic status of endometrium.

\begin{tabular}{|lll|}
\hline Type of endometrium & $\begin{array}{l}\text { Number } \\
\text { of cases }\end{array}$ & Percentage \\
\hline Proliferative & 52 & 26.40 \\
\hline Secretory & 68 & 34.52 \\
\hline $\begin{array}{l}\text { Cystoglandualr } \\
\text { hyperplasia }\end{array}$ & 59 & 29.95 \\
\hline Adenomatous hyperplasia & 11 & 5.58 \\
\hline Atypical hyperplasia & 4 & 2.03 \\
\hline Irregular shedding & 3 & 1.52 \\
\hline Irregular ripening & 0 & 0 \\
\hline Atrophic endometrium & 0 & 0 \\
\hline Total & 197 & 100.00 \\
\hline
\end{tabular}

The percentage of proliferative endometrium. was 26.40 and that of secretory endometrium was 34.52. Anovulatory endometrium was more common than secretory endometrium (63.96\% as against $36.04 \%)$.

In no patient, the endometrium showed irregular ripening, atrophic pattern and tuberculous infection.

Menorrhagia was the commonest mode of presentation in all the age group, $50 \%$ in the group $<20$ years, $38.66 \%$ in reproductive age and $30.26 \%$ in the age group $>40$ years.

Metrorrhagia and metropathia haemorrhagica were found in $20.17 \%$ and $21.85 \%$ of cases in reproductive age group and in $21.05 \%$ and $17.11 \%$ of cases in the age group $>40$ years. 
Table 5: Types of menstrual bleeding in relation to age group.

\begin{tabular}{|llllllll|}
$\begin{array}{l}\text { Age } \\
\text { group } \\
\text { (year) }\end{array}$ & $\begin{array}{l}\text { Number } \\
\text { of cases }\end{array}$ & Menorrhagia & Metrorrhagia & $\begin{array}{l}\text { Metropathia } \\
\text { Haemorrhagica }\end{array}$ & Polymenorrhagia & $\begin{array}{l}\text { Continuous } \\
\text { Bleeding }\end{array}$ & $\begin{array}{l}\text { Post- } \\
\text { menopausal } \\
\text { bleeding }\end{array}$ \\
\hline$<20$ & 2 & $1(50)$ & $1(50)$ & 0 & 0 & 0 & 0 \\
\hline $20-40$ & 119 & $46(38.66)$ & $24(20.17)$ & $26(21.85)$ & $12(10.08)$ & $11(9.24)$ & 0 \\
\hline$>40$ & 76 & $23(30.26)$ & $16(21.05)$ & $13(17.11)$ & $7(9.21)$ & $8(10.53)$ & $9(11.84)$ \\
\hline
\end{tabular}

\section{DISCUSSION}

197 cases presented with dysfunctional uterine bleeding were analysed for age, parity, types of menstrual bleeding, histological pattern of the endometrium and were correlated with each other. Now, the present study will be compared with the study done by various other authors.

Table 6: Comparative analysis of incidence of dub according to age group as reported by different authors.

\begin{tabular}{|llllllll|}
\hline $\begin{array}{l}\text { Age } \\
\text { group }\end{array}$ & $\begin{array}{l}\mathbf{N}=1000 \\
\text { Sutherland }\end{array}$ & $\begin{array}{l}\text { N=117 } \\
\text { Das A }\end{array}$ & $\begin{array}{l}\text { N=357 } \\
\text { Devi PK }\end{array}$ & $\begin{array}{l}\text { N=208 } \\
\text { Joshi SK }\end{array}$ & $\begin{array}{l}\text { N=150 } \\
\text { Kanakadurgamba }\end{array}$ & $\begin{array}{l}\text { N=552 } \\
\text { Wagh KV }\end{array}$ & $\begin{array}{l}\text { N=197 } \\
\text { Present study }\end{array}$ \\
\hline$<20$ & 3.9 & 14.5 & 23 & 9.62 & 16 & 17.57 & 1.02 \\
\hline $20-40$ & 56.8 & 48.7 & 43.4 & 62.98 & 14.6 & 64.86 & 60.4 \\
\hline$>40$ & 39.3 & 4.3 & 33.6 & 27.4 & 67.3 & 17.57 & 38.58 \\
\hline
\end{tabular}

In the present study, the percentage was highest in the women of child bearing age group (60.4), which correlates with study by Sutherland (56.8), Joshi SK (62.98) and Wagh KV (64.86)..$^{5,6}$ The percentage of DUB in the women aged $>40$ years was 38.58 which correlates with the study by Sutherland (39.3) according to Devi PK. ${ }^{7}$

Table 7: Comparative analysis of percentage of dysfunctional uterine bleeding according to parity.

\begin{tabular}{|ll|l|}
\hline Parity & $\begin{array}{l}\mathrm{n}=\mathbf{2 0 8} \\
\text { Joshi SK }\end{array}$ & $\begin{array}{l}\mathrm{n}=\mathbf{1 9 7} \\
\text { Present study }\end{array}$ \\
\hline Nulliparous & 25.96 & 3.56 \\
\hline Uniparous & 12.5 & 2.53 \\
\hline $2-5$ & 36.1 & 90,35 \\
\hline 75 & 26.44 & 3.56 \\
\hline
\end{tabular}

In the present study, maximum number of cases were found in multiparous women and minimum number of cases were found in uniparous women. The percentage was 93.91 in the multiparous women (parity 2 to 5 and above) and it was 3.56 in nulliparous and 2.53 in uniparous women.

Joshi SK in his study of 208 cases found that the maximum percentage of DUB was found in multiparous women (62.54). The percentage was 25.96 in nulliparous and 12.50 in uniparous women.

According to Dass A et al in their study of 117 cases, parity did not appear to have a causal relationship as $18 \%$ of the women were nulliparous in their study. ${ }^{8}$
The maximum number of cases of DUB were in parous women in the study by Devi PK. The percentage was 72.82 in parous women (parity 1 to 6 and above) and 17.08 in nulliparous women. The maximum percentage of DUB in multiparous women in the present study was found in consistent with the study by Joshi SK. ${ }^{9}$

\section{CONCLUSION}

Majority of the patients were found in the reproduction age group with the maximum percentage in multiparous women.Menorrhagia was the commonest mode of presentation in all age group.

An ovulatory cycles were more common than ovulatory cycles in all age group. However, in patients with menorrhagia and polymenorrhagia majority had secretory endometrium (ovulatory cycles).

Most of the patients with proliferative and secretory endometrium had normal sized uterus and normal looking endometrium. Majority of the patients with cystoglandular hyperplasia had enlarged uterus and cheesy endometrium. All patients with atypical hyperplasia had cheesy endometrium and $50 \%$ had enlarged uterus.

\section{Funding: No funding sources}

Conflict of interest: None declared

Ethical approval: The study was approved by the Institutional Ethics Committee 


\section{REFERENCES}

1. Berek JS. Berek's \& Novak's Gynaecology. Dysfunctional uterine bleeding in different age groups. 14th ed. Philadelphia: Lippincott Williams \& Wilkins;2007.

2. Horne AW, Critchley HOD, Dewhurst's Textbook of Obstetrics and Gynaecology. Abnormal uterine bleeding. $8^{\text {th }}$ Edition. 2012.

3. Strickland JL, Wall JW. Abnormal uterine bleeding in adolescents. Obstet Gynaecol Clin North Am. 2003;30:321-35.

4. Mitan La, Slap GB. Adolescent menstrual disorders. update. Med Clin North Am. 2000;84:851-68.

5. Joshi deshpande DH. ACOG committee on practice bulletins Gynaec anovulatory bleeding. Int $\mathbf{J}$ Gynaeco Obstet. 2011;72:263-71.

6. Guideline ACOG. Management of anovulatory bleeding. 2008 compendium of selected publications. 2000;14:1049-56.
7. DeviPK. Management of dysfunctional uterine Bleeding. Obstet Gynaecol Cin North Am. 2008;35(2):219-34

8. Padubidri VG, Daftary SN. Hawkins and Bourne Shaw text book of gynaecology. Menorrhagia and dysfunctional uterine Bleeding. $16^{\text {th }}$ ed. Elsevier India Private Limited;2011.

9. Margolis CZ. Pediatric algorthims. J Pediatr. 1987;110:417-8

10. Stabinsky SA, Einstein M, Breen JL. Modern treatments of Menorrhagia attriutable to dysfunctional uterine bleeding. Obstet Gynaecol Surv. 1999;54(1):61-72.

Cite this article as: Loganathan M, Krishnakumar M. Histopathological study of endometrium in dysfunctional uterine bleeding. Int J Reprod Contracept Obstet Gynecol 2018;7:3497-501. 